\title{
THE EFFECT OF TOURISM VILLAGE DEVELOPMENT ON COMMUNITY EMPOWERMENT AND WELFARE IN TOURISM VILLAGE OF PANGLIPURAN, BANGLI DISTRICT OF INDONESIA
}

\author{
Windayani I.A. Ratih Sasmitha*, Marhaeni A.A.I.N. \\ Faculty of Economics and Business, University of Udayana, Bali, Indonesia \\ *E-mail: sasmitharatih@yahoo.com
}

\begin{abstract}
The development of a tourism village is an effort to reduce the outflow of profits out of the region, the benefits can be enjoyed by the community, and so, the economic exchange that occurs gives benefits to the development of the community and the region itself. The purposes of this study are: 1) to analyze the influence of the tourism villages developmenton community empowerment in Penglipuran Tourism Village, Bangli Regency; 2) analyze the influence of the tourism villages developmentand community empowerment on community welfare in Penglipuran Tourism Village, Bangli Regency; 3) analyze the role of community empowerment in mediating the influence of the development of tourism villages on the welfare of the community in Penglipuran Tourism Village, Bangli Regency; 4) design a tourism village development strategy in accordance with the conditions of the community in Penglipuran Tourism Village in Bangli Regency. This research was conducted in Penglipuran Tourism Village, Bangli Regency. The number of samples in this study based on the Slovin formula as many as 194 respondents with the sampling method used is nonprobability sampling that is a combination of accidental sampling and snowball sampling. Data collection methods used in this study were observations, structured interviews, in-depth interviews. Data analysis techniques used are descriptive analysis techniques and Structural Equation Modeling (SEM) with alternative PLS (Partial Least Square). The results of this study indicate that the development of a tourism village has a positive and significant effect on community empowerment, the development of a tourism village has a positive and significant effect on community welfare in Penglipuran Tourism Village, community empowerment has no significant effect on community welfare, the indirect effect of the development of a tourism village on community welfare through community empowerment is insignificant and the right strategy direction to be implemented is to organize events to attract tourists, increase and multiply tour packages, and preserve the cultural authenticity of Penglipuran Tourism Village.
\end{abstract}

\section{KEY WORDS}

Tourism village development, community empowerment, community welfare.

Welfare is a condition that a person can fulfill his needs that can support his quality of life so that his life is free from poverty, ignorance, fear, or worry (Rosni, 2017). Welfare is realized so that these citizens can live properly and be able to develop themselves in order to carry out their social functions well (Widyastuti, 2012). Welfare is a subjective thing. Everyone has a different outlook on life, life goals and ways of life (Putra et al., 2017).

According to Cozma and Monica (2017) tourism has a significant impact on economic development. The development of the tourism sector is shown to improve the quality of life and well-being and can provide benefits to the fulfillment of community needs (Munawaroh, 2015). Indonesia as one of the countries in the world to rely on tourism as a source of foreign exchange has various regions as tourist destinations in the world (Wijaya, 2015). The various potentials that exist in every region in Indonesia are explored to attract the interest of tourists to come to visit so that they are expected to be able to improve the welfare of the community (Miswanto, 2018).

Bali is a tourist spot that is famous for its beauty. It is very interesting to be visited by tourists as a contributor to regional income (Wilson et al., 2015). The attractiveness of Bali 
Island fascinates tourists both culture, customs and enchanting natural beauty (Sri, 2013). Besides that, the exoticism of nature and culture and its people has named Bali as the locomotive of Indonesian tourism (Sudana, 2013). Based on BPS data in Bangli Regency (2017), the increasing number of tourists coming to Bangli Regency will affect available employment opportunities. The increasing number of residents working in Bangli Regency indicates that there has been an improvement in the welfare of the Bangli people. This can also be seen from the HDI of Bangli Regency which is increasing every year even though the average is still below the average HDI of the Province of Bali. The level of community welfare can be measured through the Human Development Index (Arini, 2016).

Village tourism is one of the community-based tourism development which offers tourists to directly see, feel and interact with the villagers they visit so that tourists get a different experience from other tourist destinations. Every government program is shown to stimulate local community participation (Adi et al., 2017). The challenge faced by the tourism village is in terms of marketing or promoting the tourism village (Garrod et al., 2006). Therefore we need support from the government in terms of promotion of rural tourism.

One of the tourist villages in the Province of Bali is the Penglipuran Tourism Village. This village is the most developed tourist village in the Province of Bali. According to Section (2017) the development of a tourism village has a positive effect on the welfare of the community. This means that with the development of rural tourism can prosper the community. The results of the development of tourism villages have an impact on employment opportunities, increased income and investment growth in the tourism business for the local community (Muslim, 2016). The development of Penglipuran Tourism Village can be seen from the availability of attractions, amenities, accessibility and management institutions (Wibawa, 2018). The government and the private sector should provide more training and other assistance which is a form of community empowerment, but the training provided must be sustainable so that the benefits can be received by the village community (Sulistyawati et al., 2019).

Community empowerment provides autonomy and community responsibility to make decisions related to the goals to be achieved (Kumar and Ananda, 2017). Through the empowerment process, people gain the power to act to change their lives for the better (Kasmel \& Penille, 2011). Community empowerment to increase economic activities in the village, where the community directly participates in achieving prosperity (Rochman, 2016). According to Sari and Heryanto (2012) one example of the influence of the development of a tourism village on community empowerment was that before the village tourism community only farmed / planted with low income, but now with the development of a tourist village many communities have established businesses that sell products village products. This shows that community empowerment activities through the village tourism program have been carried out by local communities. According to Andriyani (2017), other forms of community empowerment through the development of tourism villages in Penglipuran Village can be seen from the community's involvement directly or indirectly in the tourism village development program.

According to Sururi (2015), community empowerment as a development concept encapsulates social and cultural values that develop dynamically in the community and reflects the development paradigm that is people centered or centered on society as the subject and agent of development. With community empowerment, it is expected to improve mental and spiritual, improve education and skills, improve the quality and quantity of family food, improve mental and physical health (Ansar, 2017).

The objectives of this study are: 1) to analyze the influence of the development of tourism villages on community empowerment in Penglipuran Tourism Village, Bangli Regency; 2) analyze the influence of the development of tourism villages and community empowerment on community welfare in Penglipuran Tourism Village, Bangli Regency; 3) analyze community empowerment in mediating the influence of the development of tourism villages on the welfare of the community in Penglipuran Tourism Village, Bangli Regency; 4) design a tourism village development strategy in accordance with the conditions of the community in Wisatsa Penglipuran Village in Bangli Regency. 


\section{LITERATURE REVIEW}

Law Number 10 of 2009 concerning Tourism mandates that one of the objectives of tourism activities is to preserve nature, the environment and resources based on the principles of preserving nature and the environment, empowering local communities and ensuring integration between sectors, between regions, between central and regional which is a systemic unit in the context of regional autonomy and integration among stakeholders.

Community-based tourism can be one way to create sustainable tourism (Blackstock, 2005). The purpose of community-based tourism is to empower the community, encourage community participation in the decision making process, and distribute income to the community (Mclntyre, 1993; Choi \& Ersan 2013). According to Salazar (2011), Community Based Tourism generates employment opportunities and contributes to the development of benefits mainly received by local communities. According to Pokaiyaudom (2013), the focus of community-based tourism is the participation of local communities in it. The role of the private sector, government and community in CBT implementation is needed (Mtapuri \& Andrea, 2014). Community participation in tourism ensures better opportunities for local people to benefit from tourism activities (Sebele, 2010).

According to Amalia, et al (2018), the development of tourism villages creates new economic activities for the community. A tourism village is a rural area that offers an overall atmosphere that reflects the authenticity of the countryside both from socio-economic life, socio-culture, daily customs, has architectural buildings, and a typical village spatial structure, or interesting economic activities and has the potential to develop various tourism component, such as attractions, accommodation, food-drinks and other tourism needs (Hadiwijoyo, 2012; Fitari and Samsul, 2017).

According to Laverack (2005), community empowerment is an important process in community development. In supporting community empowerment, training can be done according to their abilities (Seran et al., 2017). Conceptually, community empowerment is an effort to improve the dignity of the layers of society that in their present condition are unable to escape poverty (Sururi, 2017). Terry Wilson in the Handbook of Empowerment, states that empowerment is to increase the motivation and results of all company employees through the delegation and transfer of power (Wilson, 2004; Moraless et al., 2013).

Public welfare is a condition of meeting basic needs as reflected by a decent home, adequate clothing and food needs, cheap and quality education and health costs or conditions where each individual is able to maximize his utility at a certain budget level and conditions where physical and spiritual needs are met.

Assumptions on the theory of human capital state that an additional one year of continuing school means that on the one hand it can improve one's work skills and abilities but on the other hand it will delay income for one year of education. Education has an influence on economic growth because education plays a role in increasing labor productivity. This human capital theory considers formal education is a good investment for a person or for the community.

\section{CONCEPTUAL FRAMEWORK}

The development of a tourism village to be sustainable and provide maximum benefits must be focused on four important components, namely attractions, amenities, accessibility, and management institutions. According to Section (2017) the development of a tourism village has a positive effect on people's welfare. Communities can get business opportunities from something unique that is owned from the village will increase local people's income. In the development of rural tourism communities are empowered through tourism (Pramanik, 2019). According to Sari and Heryanto (2012) the role of the development of a tourism village towards community empowerment was prior to the existence of a tourist village where the community only did farming / gardening improperly, but since the existence of a tourist village many communities have established businesses such as special food, souvenirs typical of a 
tourist village even open a homestay that can be rented by tourists who come to the tourist village. This shows the community empowerment activities through the rural tourism program. According to Andriyani (2017) the process of developing Penglipuran Tourism Village involves local people as workers both as managers of tourism villages, cleaning staff and workers for the construction of tourism support infrastructure. The development of a tourism village as one of the programs for community empowerment is intended to realize the independence of the community to be able to live well through the utilization of the potential that is owned in a village (Mustagin et al., 2017).

Community empowerment influences community welfare. Welfare was obtained because of the existence of community empowerment given socialization, assistance and training from the government so that people know the targets to be achieved for the welfare of the community (Lalaun \& Agus, 2015). Community empowerment is essentially directed to improve access to prosperous life for individuals, families and community groups with resources to conduct production processes and business opportunities. To be able to achieve this, various efforts to motivate are needed in the form of capital assistance and human resource development (Sururi, 2015). Community empowerment is a process that develops and strengthens the community's ability to continue to be involved in the development process that takes place dynamically so that the community can solve the problems they face (Adnan, 2012). The more empowered the community is and supported by the ability (self potential), the better the level of community welfare. Based on the data analysis technique used, the SEM will know the effect of the development of the tourism village on empowerment and welfare of the community in the Tourism Village of Panglipuran, Bangli Regency. The following is presented in Figure 1 the path diagram of this study is as follows.

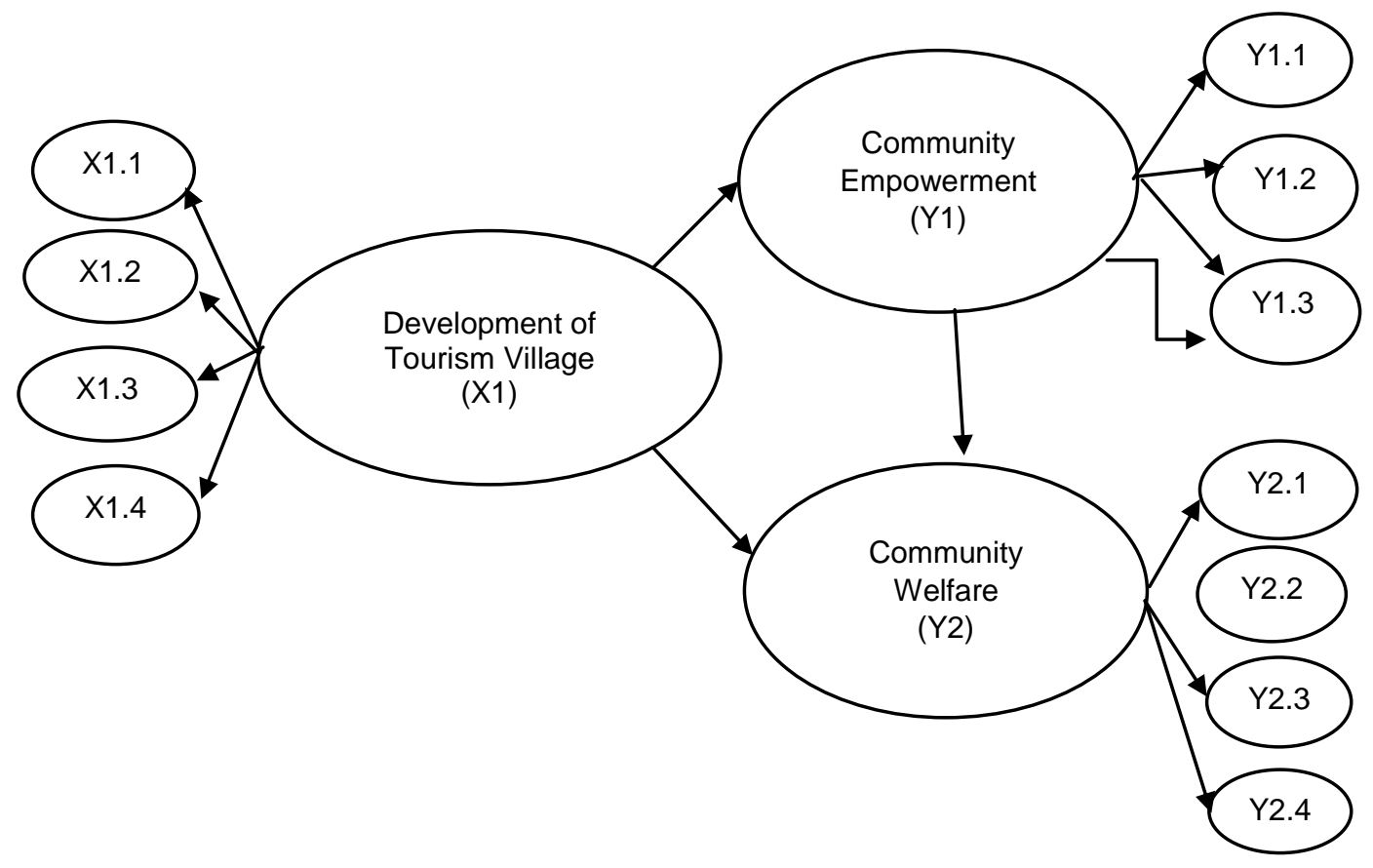

Figure 1 - Conceptual Framework

Based on the theoretical and empirical studies, the following hypotheses of the research variables can be formulated:

- Tourism village development has a positive effect on community empowerment in Penglipuran Tourism Village, Bangli Regency;

- Tourism village development and community empowerment have a positive effect on the welfare of the community in Penglipuran Tourism Village, Bangli Regency;

- Community empowerment mediates the influence of developing tourist villages on community welfare in Penglipuran Tourism Village, Bangli Regency. 


\section{METHODS OF RESEARCH}

The form of this research is descriptive-associative. Descriptive research is used to analyze the strategy of developing a tourism village in accordance with the conditions of the Penglipuran Tourism Village community. Associative research is used to analyze the influence or relationship between the variables of tourism village development towards community empowerment and community welfare in Penglipuran Tourism Village, Bangli Regency. In this study there are three hypothesis formulations. This research was conducted in Penglipuran Tourism Village, Bangli Regency. The variables used in this study are the development of a tourist village as measured by indicators of attraction availability, availability of amenities, availability of access, availability of institutions. The variable of community empowerment is measured through indicators of awareness, capacity building, and empowerment. The variable of community welfare is measured by indicators of income, education, health, security.

The type of data used in this study is quantitative data, namely the population of Panglipuran tourism village in Bangli district and the Human Development Index (HDI) of the Province of Bali, and qualitative data, namely the information provided by respondents regarding the questions given by researchers. The qualitative data obtained from this study are the opinions of respondents regarding the development of tourism villages, community empowerment and community welfare. The population of this study were all people of Penglipuran Tourism Village in Bangli Regency who were at productive age who were involved / working in tourism activities in Penglipuran Tourism Village. The sampling method used is nonprobability sampling which is a combination of accidental sampling and snowball sampling. The number of samples in this study based on the Slovin formula was 194 respondents. Data analysis techniques used are descriptive analysis techniques and Structural Equation Modeling (SEM) with alternative PLS (Partial Least Square). The equation model in this study is in accordance with Figure 1 namely:

$$
\begin{gathered}
Y_{1}=\beta_{1} X_{1}+e_{1} \\
Y_{2}=\beta_{2} X_{1}+\beta_{3} Y_{1}+e_{2}
\end{gathered}
$$

Where: $X_{1}=$ Development of Tourism Village, $Y_{1}=$ Community Empowerment, $Y_{2}=$ Community Welfare, $\beta_{1-2-3}=$ Regression coefficient and $e_{1}, e_{2}=$ error.

\section{RESULTS AND DISCUSSION}

The convergent validity of a measurement model that has a reflective indicator can be assessed from the loading factor (ie the correlation between item scores / component scores and construct scores) indicators that measure the construct. An indicator can be declared valid if it has a loading factor above 0.7 against the intended construct. In this research, all loading factor indicators have values greater than 0.7 . This shows that the convergent validity requirements have been fulfilled. The measurement of discriminant validity of the measurement model can be assessed based on the cross loading measurement indicators with their constructs. If the correlation indicator construct has a higher value than the correlation indicator with other constructs, then it is said that the construct has high discriminant validity. Composite Reliability and Cronbach's Alpha are generally used reflective indicators that aim to measure the internal consistency of a construct. The Cronbach's Alpha or Composite Reliability score must be greater than 0.7 , but if the results are close to 0.7 (such as 0.6), it is still acceptable in exploratory studies (Hair et al, 2006). This study shows the value of Cronbach's Alpha and Composite Reliability of each construct that is of greater value or close to 0.70 so that it can be said that the gauges in this study are reliable.

The development of a tourism village has a positive and significant effect on community empowerment of 0.444 with $p$ value $=0.000$, with the equation function $\mathrm{Y} 1=0.444 \mathrm{X} 1$. Based 
on these results it can be stated that the better the development of a tourist village, the community conditions in the tourist village will be more empowered. According to I Wayan Supat, Bendesa adat in Penglipuran Tourism Village in an interview on August 16, 2019 said the results were in line: "With the development of a tourist village, more and more tourists coming to this tourism village have encouraged the community to participate in supporting tourism. More and more tourists visit, here the community will interact with tourists, from this interaction will increase community awareness and knowledge even the community will find new job opportunities supported by socialization, training and even capital assistance from the government ".

The development of a tourism village has a positive and significant influence on people's welfare by 0.674 with $p$ value $=0.000$, the variable of community empowerment has no significant effect on people's welfare, with a coefficient of -0.077 with the equation function $\mathrm{Y} 2=0.674 \mathrm{X} 1-0.077 \mathrm{Y} 1$. The better the development of the tourism village, the condition of the community in the tourist village will be more prosperous. Through the results of an interview with I Wayan Bona, Head of the Tourism and Culture Office of the Bangli Regency on September 3, 2019 stating that: "Revenues generated through the Penglipuran Tourism Village will be enjoyed by the tourism village. Other indirect income is from the sale of souvenirs, food and beverages, homestays, events and outbound, whose annual turnover of money can reach billions of rupiah from various existing tourist attractions. So that it can be concluded that tourism has brought the welfare of Penglipuran Village community to a much better level. "The discussion is supported by research from Hermawan (2016), the development of tourism villages has a positive impact on people's income. Income increases occur in various fields of community livelihoods such as traders, tourism service workers and so on.

Community empowerment has no direct effect on community welfare. Based on previous research, Heryani and Fadjar (2017) stated that the effect of empowerment on community welfare is concluded that empowerment is less able to reach the goal, namely welfare. This is due to various obstacles that arise, such as the ineffectiveness of community empowerment related to efforts to improve the economy / welfare and insufficient support / facilitation that results in the marginalization of businesses owned by the community. Based on previous research, Heryani and Fadjar (2017) stated that the effect of empowerment on community welfare is concluded that empowerment is less able to reach the goal, namely welfare. This is due to various obstacles that arise, such as the ineffectiveness of community empowerment related to efforts to improve the economy / welfare and insufficient support / facilitation that results in the marginalization of businesses owned by the community.

The indirect effect of the tourism village development variable on community welfare through community empowerment was obtained t-statistic $(1.035)<t$ table (1.65), so the community empowerment hypothesis mediated the effect of the development of the tourism village on community welfare was rejected. According to I Wayan Supat, the Bendesa adat in the Penglipuran Tourism Village in an interview on August 16, 2019 stated: "Through the development of the tourist village training forms provided to the Penglipuran Village community such as dance training from dance studios from outside the village, assistance and monitoring for example from the Indonesian Guides Association (HPI). However, these activities are not routinely carried out. In terms of government funding, the community does not receive direct financial assistance from the government to support their efforts, for example, but one form of assistance from the government is that the government has granted a homestay to be managed by a tourism village. "

Penglipuran Tourism Village Development with a score of $S<0$, which is a greater opportunity than the existing strength, where the direction of Penglipuran Tourism Village Development strategy is a stable growth strategy. Positive internal and external factors mean that the strengths of Penglipuran Tourism Village Development are relatively superior compared to its weaknesses, while the environmental opportunities currently faced are greater than the threats. So that the right strategic direction to be implemented is to hold events to attract tourists, increase and increase tour packages, and preserve the cultural authenticity of Penglipuran Tourism Village. 


\section{CONCLUSION AND RECOMMENDATIONS}

The development of tourism villages has a positive and significant effect on community empowerment. The development of a tourism village will play a role in helping community empowerment in the Penglipuran Tourism Village. With the development of the tourism village, it is necessary to involve the local community in managing the tourism village as an effort to empower the community. The development of a tourism village has a positive and significant effect on the welfare of the people in Penglipuran Tourism Village. This means that the development of Penglipuran Tourism Village has an impact on the economy which includes increasing people's income and creating new jobs, while community empowerment has no significant effect on community welfare. The indirect effect of developing tourist villages on community welfare through community empowerment is insignificant. That is, community empowerment does not mediate the influence of the development of tourism villages on welfare in penglipuran tourism villages. The development of Penglipuran Tourism Village is relatively superior compared to its weaknesses, while the environmental opportunities currently faced are greater than the threats. So that the right strategic direction to be implemented is to hold events to attract tourists, increase and increase tour packages, and preserve the cultural authenticity of Penglipuran Tourism Village.

Based on the results of research, suggestions that need to be done socialization, coaching, assistance, and intensive empowerment assistance as a whole to all the community as well as Pokdarwis and managers of Penglipuran Tourism Village. Local and village governments need to work together with third parties such as experienced tourism industry players so that the community becomes interested and enthusiastic to participate in training. Strengthening cooperation between the government, private sector, and the community and creating good and intensive communication to realize programs that support the welfare of the people in Penglipuran Tourism Village.

\section{REFERENCES}

1. Adi, I Nyoman Rasmen, Made Suyana Utama, Made Kembar Sri Budhi, Ida Bagus Putu Purbadharmaja. 2017. The Role of Government in Community Based Tourismand Sustainable Tourism Development at Penglipuran Traditional Village-Bali. IOSR Journal of Humanities And Social Scene Vol. 22 Issue 6.

2. Adnan, Wan. 2012. Upaya Peningkatan Kesejahteraan Keluarga Memanfaatkan Program Nasional Pemberdayaan Masyarakat (PNPM) Mandiri Pedesaan. Jurnal Tesis PMIS UNTAN PSIS.

3. Amalia, Nikita, Andriani Kusumawati \& Luchman Hakim. 2018. Partisipasi Masyarakat Dalam Pengembangan Desa Wisata Serta Dampaknya Terhadap Perekonomian Warga Di Desa Tulungrejo Kota Batu. Jurnal Administrasi Publik, 61(3).

4. Andriyani, Anak A. Istri. 2017. Pemberdayaan Masyarakat Melalui Pengembangan Desa Wisata dan Implikasinya Terhadap Ketahanan Sosial Budaya Wilayah. Jurnal Ketahanan Nasional, 23(1).

5. Anshar, Muhhamad. 2017. Peran dan Dampak Program Pemberdayaan dan Kesejahteraan Keluarga Terhadap Kesejahteraan Ekonomi Warga Kelurahan Sei Kera Hilir II Kota Medan. Jurnal UINSU.

6. Arini, Prima R. 2016. Pengaruh Belanja Modal Terhadap Pertumbuhan Ekonomi dan Kesejahteraan Masyarakat Di Pulau Kalimantan. Jurnal Riset Akuntansi Mercu Buana, 2(2).

7. Bagiana, Yogi Sutanegara. 2017. Pengembangan Desa Wisata Terhadap Krsejahteraan Masyarakat Desa Penglipuran, Kecamatan Bangli, Kabupaten Bangli. E-Jurnal Ekonomi Pembangunan Universitas Udayana, 6(9).

8. Blackstock, Kristy. 2005. A critical look at community based tourism. Community Development Journal, 40(1). 
9. Choi, Hwan Suk Cris, Ersan Sirakaya. 2005. Measuring Resident Attitude toward Sustainable Tourism: Development of Sustainable Tourism Attitude. Journal of Travel Research.

10. Cozma, Adeline C. \& Monica Maria C. 2017. Tourism Development In Rodna Mountains National Park: The Public Administration, A Key Stakeholder. Journal Of Tourism.

11. Fitari, Y. \& Samsul Ma'rif. 2017. Manfaat Pengembangan Desa Wisata Wonolopo terhadap Kondisi Sosial, Ekonomi, dan Lingkungan Masyarakat Lokal. Jurnal Wilayah dan Lingkungan, 5(1).

12. Garrod, Brian, ROZ Wornell \& Ray Youell. 2006. Re-conceptualing Rural Resources As Countryside Capital: The Case of Rural Tourism. Journal Of Rural Studies, 22, p: 117-128.

13. Hermawan, Hary. 2016. Dampak Pengembangan Desa Wisata Nglanggeran Terhadap Ekonomi Masyarakat Lokal. Jurnal Pariwisata, 3(2).

14. Heryani, Dian dan Fadjar Hari Mardianjah. 2017. Pemberdayaan Ekonomi Produktif Dalam Penanggulangan Kemiskinan Perdesaan Di Kabupaten Rembang. Jurnal Pembangunan Wilayah \& Kota, Vol. 13 No.1.

15. Kasmel, A. \& Penille Tanggaard Andersen. 2011. Measurement of Community Empowerment in Three Community Programs in Rapla (Estonia). Internasional Journal Of Environmental Research and Public Health, 8, p:799-817.

16. Kumar, Jaya, Ananda Kumar. 2017. Employe Empowernment-An Empirical Study. Global Journal Of Management and Business: Administration and Management, 17(4)

17. Lalaun, Albertus \& Agus Siahaya. 2015. Dampak Program Pemberdayaan Terhadap Kesejahteraan Masyarakat Kecamatan Yaru Kabupaten Maluku Tenggara Barat. Jurnal Administrasi Publik, 5(2).

18. Laverack, Glenn. 2005. Using a Domains Approach to Build Community Empowerment. Community Development Journal.

19. Mtapuri, Oliver \& Andrea Giampiccoli. 2014. Toward a Comprehensive Model of Community-based Tourism Development. South African Geographical Journal, 98(1).

20. Miswanto. 2018. Dampak Pembangunan Industri Pariwisata Terhadap Alih Fungsi Lahan (Studi Tentang Kehidupan Sosial Budaya Masyarakat Desa Teluk Bakau, Kecamatan Gunung Kijang, Kabupaten Bintan, Kepulauan Riau). Jurnal Antropologi: Isu-isu Sosial Budaya, 20(1).

21. Morales, Heriberto Niccolas, Jaime Garnica Gonzales \& Arturo Torres Mendozza. 2013. Empowernment As A Culture and Strategy To Streghten The Activities Of Resesrch And Innovation:Proposal Of Methodology. European Scientific Journal, Vol.1

22. Munawaroh, Rina. 2015. Partisipasi Masyarakat dalam Pengembangan Pariwisata Berbasis Masyarakat di Taman Nasionak Gunung Merbabu Suwantin, Magelang. Jurnal Elektronik Mahasiswa Pend. Luar Sekolah, 6(4).

23. Muslim, Azis. 2016. Economic Community Empowerment through Tourist Village Development. MIMBAR, 32(2).

24. Mustagin, Desy Kusniawati, Nufa Pramina Islami, Baruna Setyaningrum \& Eni Prasetyawati. 2017. Pemberdayaan Masyarakat Berbasis Potensi Lokal Melalui Program Desa Wisata Di Desa Bumiaji. Jurnal Pemikiran dan Penelitian Sosiologi, 2(1).

25. Noor, Munawar. 2011. Pemberdayaan Masyarakat. Jurnal IImiah CIVIS, 1(2).

26. Pokaiyaudom, Gulapish. 2013. The Integrated Learning of Community Based Tourism in Thailand. Social and Behavioural Science.

27. Pramanik, Purwanti Dyah, Rahmat Ingkadijaya \& Mochamad Achmadi.. 2019. The Role of Social Capital in Community Based Tourism. Journal Of Indonesian Tourism and Development Studies.

28. Putra, Raden Ahmad Romadhoni Surya, Bambang Ariyadi, Novita Kurniawati \& Fransiskus Trisakti Haryadi. 2017. Pengaruh Modal Sosial Terhadap Tingkat Kesejahteraan Rumah Tangga Peternak: Studi Kasus Pada Kelompok Peternak Ayam Kampung Ngudi Mulyo, Gunung Kidul. Buletin Peternakan, 41(3). 
29. Rochman, Noor. 2016. Model Pengembangan Desa Wisata Berbasis Pemberdayaan Masyarakat. Jurnal Equilibria Pendidikan, 1(1).

30. Salazar, Noel B. 2011. Community-based cultural tourism: issues, threats and opportunities. Journal of Sustainable Tourism, 20(1), p: 9-22.

31. Sari, Gita Erlita \& Heryanto Susilo. 2012. Pemberdayaan Masyarakat Melalui Pengembangan Desa Wisata Agropolitan Sebagai Upaya Menambah Pendapatan Keluarga di Desa Karangsono Kecamatan Kanigoro Kabupaten Blitar. Jurnal Mahasiswa Unesa.

32. Sebele, Lesego S. 2010. Community Based Tourism Ventures, Benefits and Challenges: Khama Rhino Sanctuary Trust, Central District Bostwana. Tourism Management Journal, 31, p: 136-146.

33. Seran, Etni Debora, Arie J. Rorong \& Very Y. Londa. 2017. Pengaruh Pemberdayaan Usaha Kecil dan Menengah Terhadap Kesejahteraan Masyarakat di Kecamatan Tompaso Barat Kabupaten Minahasa. Jurnal Administrasi Publik.

34. Sri, Anak Agung Putri. 2013.Faktor-faktor Yang Memotivasi Perempuan Sebagai Pengelola Pondok Wisata di Kelurahan Ubud. Analisis Pariwisata, Vol.13 No.1.

35. Sudana, I Putu. 2013. Strategi Pengembangan Desa Wisata Ekologis di Desa Wisata Belimbing, Kecamatan Pupuan, Kabupaten Tabanan. Analisis Pariwisata 13(1).

36. Sulistyawati, Agung Sri, Fanny Maharani Suarka \& Putu Ratih Pertiwi. 2019. Pelibatan Masyarakat Lokal Dalam Penyediaan Penginapan Lokal (Homestay) di Desa Wisata Tista, Kabupaten Tabanan. Jurnal Perhotelan dan Pariwisata.

37. Sururi, Ahmad. 2017. Pemberdayaan Masyarakat Melalui Program Pembangunan Infrastruktur Perdesaan dalam Meningkatkan Kesejahteraan Masyarakat Kecamatan Wanasalam kabupaten Lebak. Jurnal Administrasi Negara, 3(2), p: 1-25.

38. Wibawa, Indra. 2018. Pengaruh Kebijakan Pemerintah, Partisipasi Masyarakat dan Kewirausahaan Terhadap Kualitas Destinasi Wisata Pura Taman Ayun. E-Jurnal Ekonomi dan Bisnis Universitas Udayana.

39. Widyastuti, Astriana. 2012. Analisis Hubungan Antara Produktivitas Pekerja dan Tingkat Pendidikan Pekerja Terhadap Kesejahteraan Keluarga Di Jawa Tengah Tahun 2009. Economics Development Analysis Journal, 1(1).

40. Wijaya, Kandi. 2015. Masa Depan Pariwisata Bali (Perspektif Permasalahan dan Solusinya). Jurnal Riset Ekonomi dan Manajemen, 15(1).

41. Wilson, Suzanne, Daniel R. Fesenmaier, Julie Fesenmaier \& John C. Van Es. 2015. Factors for Success in Rural Tourism Development. Journal Of Travel Research, 40(2). 